\title{
Thematic structure of research on crop weeds in Poland
}

\author{
Bogdan Jackowiak
}

Department of Plant Taxonomy, Faculty of Biology, Adam Mickiewicz University in Poznań, Umultowska 89, 61-614 Poznań, Poland, e-mail: bogjack@amu.edu.pl

\begin{abstract}
The paper presents an analysis of problems of arable field weeds discussed by Polish authors in 2853 botanical scientific works published in the years 1870-2015. The research included both widely available publications and scientific works that appeared in Polish in regional and local journals, as well as the brief conference proceeding. The thematic structure of Polish studies on segetal weeds consists of several levels and includes eight main thematic groups and 51 subgroups. The review and multi-subject works were included in the ninth group. Taking into account the number of publications, main thematic groups are ranked as follows: (1) Weed flora and vegetation: structure, distribution and dynamics; (2) Weediness of different crop types, crop fields and fallow lands; (3) Interactions between weeds and the environment; (4) Biology and weed development; (5) Variability, taxonomy and weed diagnostics; (6) Research methodology; (7) Extinction and protection of weeds; (8) Weeds of archaeological localities.
\end{abstract}

Key words: crop weeds, weediness, weed infestation, segetal flora, segetal communities, topics of research, Poland

\section{Introduction}

The Polish landscape is dominated by agricultural land, which covers over $60.1 \%$ of the country's area. About $31 \%$ is covered by forests, while the remainder is occupied by urban areas $(5.3 \%)$, water bodies, watercourses and wetlands $(2.1 \%)$ and wastelands $(1.6 \%)$. The largest part of agricultural land are the sown areas $(73 \%)$. In total, about $25 \%$ of the area of agricultural land is taken up by meadows $(19 \%)$, pastures (3\%) and permanent crops (3\%). The crop structure is dominated by cereals $(71 \%)$. Industrial plants make $11 \%$, fodder $10 \%$ and potatoes $8 \%$ of the sown areas (MRSP 2017).

An important component of agrocoenoses are weeds, i.e., plants that spontaneously occurr among cultivated plants. Segetal weeds and their communities constitute an extremely important component of Poland's vegetation, especially if one considers the huge area of arable land in this country.

The crop weeds (segetal weeds) have long attracted interest of both agricultural and agrotechnical sciences as well as geobotanics. In Poland, scientists representing these two areas cooperate closely, organizing joint conferences every year for over 40 years (Table 1 ). The result of this cooperation are considerable scientific achievements and development of important applications. However, these studies have not yet received a comprehensive synthesis, although many original publications summarizing specific issues have appeared. It seems that the necessary step in this direction may be the systematization of knowledge about research problems presented in the publications of Polish authors. The development of such classification is the main objective of this paper.

\section{Material and methods}

The subject of the analysis were the scientific works of Polish authors, which were published up to 2015 and related to the botanical aspects of the occurrence of weeds in field and garden crops and on fallow lands. These works were collected in a series consisting of five bibliographies titled "Distribution, ecology and biology of segetal weeds" (Jackowiak \& Latowski 1996; Latowski \& Jackowiak 2001, 2006, 2011, 2016). This statement mainly includes original research works, as well as review publications, discussion articles, scientific reports and conference announcements. The above series of bibliographies includes mainly papers that discuss weeds from the botanical point of view, while publications focused on agrotechnical issues have been omitted. The decision to include or reject a given paper was made based on the analysis of the following features of a publication: title, scientific problem, 
key words, hypotheses, and the aim and methods of research.

The detailed analysis of each publication was also the basis of the first step of classification leading to the elaboration of the thematic structure of scientific papers devoted to segetal weeds (Fig. 1). In the second stage, specific research problems were combined into groups of increasingly higher level of generality, which resulted in a multi-level, hierarchical thematic structure. In the third stage of research, each publication was sought to be included in a specific thematic group. Publications, which due to thematic diversity could not be assigned to a defined category, were included in a separate group (No 9). The results of the classification were elaborated

Table 1. Themes of National Conferences from the series "Regionalization of segetal weeds in Poland"

\begin{tabular}{|c|c|c|c|}
\hline Number & Year & Place & Title \\
\hline 0 & 1976 & Wrocław & Methodical bases of an analysis of weedness \\
\hline 1 & 1977 & Lublin & Flora and segetal communities \\
\hline 2 & 1978 & Łódź & Some aspects of ecology of segetal weeds \\
\hline 3 & 1979 & Szczecin & Some aspects of ecology of segetal weeds \\
\hline 4 & 1980 & Olsztyn & Some aspects of ecology of segetal weeds \\
\hline 5 & 1981 & Kraków & Some aspects of ecology of segetal weeds \\
\hline 6 & 1982 & Gdańsk (Stare Pole) & $\begin{array}{l}\text { Some geographic and ecological aspects of segetal vegetation of } \\
\text { Western Pomerania }\end{array}$ \\
\hline 7 & 1983 & Warszawa & Segetal communities of Mazovia \\
\hline 8 & 1984 & Słupsk (Redło) & Selected aspects of segetal weed ecology of Middle Pomerania \\
\hline 9 & 1985 & Poznań (Sielinko) & Distribution, ecology and biology of weeds \\
\hline 10 & 1986 & Rzeszów & Distribution, ecology and biology of weeds \\
\hline 11 & 1987 & Wrocław & Dynamics of field weediness \\
\hline 12 & 1988 & Katowice (Bielsko-Biała) & Occurrence of Agropyron repens in crop fields \\
\hline 13 & 1989 & Siedlce & Problem of weeds on light soils and methods of weed control \\
\hline 14 & 1990 & Wrocław (Wysoka) & Computer techniques - weed research methodology \\
\hline 15 & 1991 & Kraków & Weediness of crops in the years $1980-1990$ \\
\hline 16 & 1992 & Lublin & Problem of weeds in the secondary fallow lands \\
\hline 17 & 1993 & Szczecin & $\begin{array}{l}\text { Changes in field weediness caused by the difficult economic situation } \\
\text { of agriculture }\end{array}$ \\
\hline 18 & 1994 & Olsztyn (Bęsia) & Causes and sources of field weediness \\
\hline 19 & 1995 & Bydgoszcz & Expansive segetal weeds \\
\hline 20 & 1996 & Łódź & Endangered and threatened species of segetal flora \\
\hline 21 & 1997 & Wrocław & Secondary weediness of root crops and stubble weeds \\
\hline 22 & 1998 & Wrocław (Łosiów) & Effect of the flood in 1997 in field weediness \\
\hline 23 & 1999 & Skierniewice & $\begin{array}{l}\text { Penetration of ruderal species from orchard and park habitats into } \\
\text { vegetable and agricultural plant communities }\end{array}$ \\
\hline 24 & 2000 & Siedlce & Weed communities in ecological farms \\
\hline 25 & 2001 & Wrocław & $\begin{array}{l}\text { Participation of Amaranthus retroflexus, Chenopodium album and } \\
\text { Echinochloa crus-galli in segetal communities }\end{array}$ \\
\hline 26 & 2002 & Słupsk (Ustka) & Segetal plants as bioindicators \\
\hline 27 & 2003 & Kraków (Krynica) & Segetal weeds - positive aspects of their occurrence in agrocoenoses \\
\hline 28 & 2004 & Olsztyn & Secondary succession of vegetation in post-agricultural land \\
\hline 29 & 2005 & Poznań (Czerniejewo) & Segetal flora and vegetation of protected areas \\
\hline 30 & 2006 & Wrocław (Krzyżowa) & Dynamics of segetal communities in farms differing in ways of farming \\
\hline 31 & 2007 & Lublin & Biology of segetal weeds \\
\hline 32 & 2008 & Rzeszów & $\begin{array}{l}\text { Vegetation accompanying energy crops and biology of selected species } \\
\text { of weeds }\end{array}$ \\
\hline 33 & 2009 & Siedlce & $\begin{array}{l}\text { Migration of species and the role of migrating species in segetal } \\
\text { communities, and biology of weeds of the family Poaceae }\end{array}$ \\
\hline 34 & 2010 & Bydgoszcz & $\begin{array}{l}\text { Dynamics of segetal vegetation in the investment areas and biology of } \\
\text { selected weeds in a suburban zone }\end{array}$ \\
\hline 35 & 2011 & Wrocław (Winna Góra) & Biodiversity of weed communities of agricultural lands \\
\hline 36 & 2012 & Zamość & $\begin{array}{l}\text { Species diversity of segetal weed communities depending on the usage } \\
\text { of agricultural lands }\end{array}$ \\
\hline 37 & 2013 & Słupsk (Ustka) & $\begin{array}{l}\text { Occurrence of Phalaris arundinacea and Calamagrostis epigeios in the } \\
\text { agro-industrial areas }\end{array}$ \\
\hline 38 & 2014 & Poznań & Changes in the species composition of agrocoenoses in the last 50 years \\
\hline 39 & 2015 & Olsztyn & Biology of weeds \\
\hline
\end{tabular}




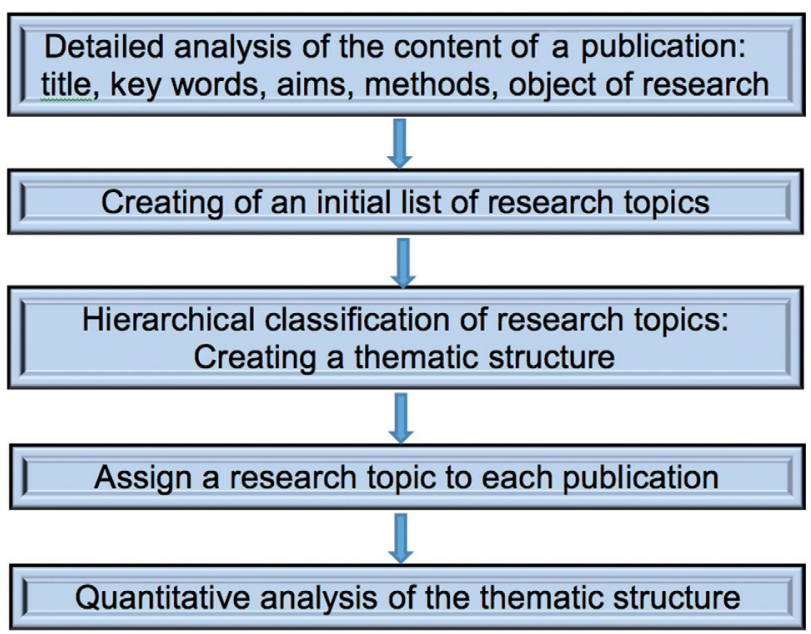

Fig. 1. Schematic diagram of the thematic classification of research on crop weeds in Poland

in the form of simple descriptive statistics that show the proportions between thematic groups and subgroups as well as the dynamics of publishing in the analyzed period.

\section{Results}

3.1. Publishing dynamics in the years $1870-2015$

In less than 150 years, Polish authors published 2853 papers devoted to the weeds of arable fields. The first publications appeared in the second half ofthe nineteenth century (Rehman 1870, 1871; Tyniecki 1875). Regular research of segetal plants began 70 years later. Initially, only single publications were issued during the year. Particularly the works of Professor Jan Kornaś were of key importance for the development of geobotanical research on crop weeds in Poland (1950a, 1950b, 1954, 1959). Since 1960, the number of publications on segetal weeds began to increase and during the years 1970 to 1975 exceeded the average of 20 per year (Fig. 2). This coincides with two important events for the development of geobotanical research in Poland: firstly, a series of symposia on the synanthropisation of plant cover, organized on the initiative of Professor Janusz B. Faliński (1968, 1971, 1972, 1976), and secondly, a series of nationwide scientific conferences titled "Regionalization of segetal weeds in Poland", organized by Professor Zygmunt Rola (Table 1).

After a short break in the growth dynamics in the years 1990-1995, the number of publications increased sharply again in the first decade of the twenty-first century, exceeding 100 papers published during the year.

3.2. The thematic structure of Polish publications on distribution, ecology and biology of segetal weeds

Based on the content analysis of all publications, eight main thematic groups, divided into 51 subgroups, were distinguished (Table 2). Over $80 \%$ of the works belong

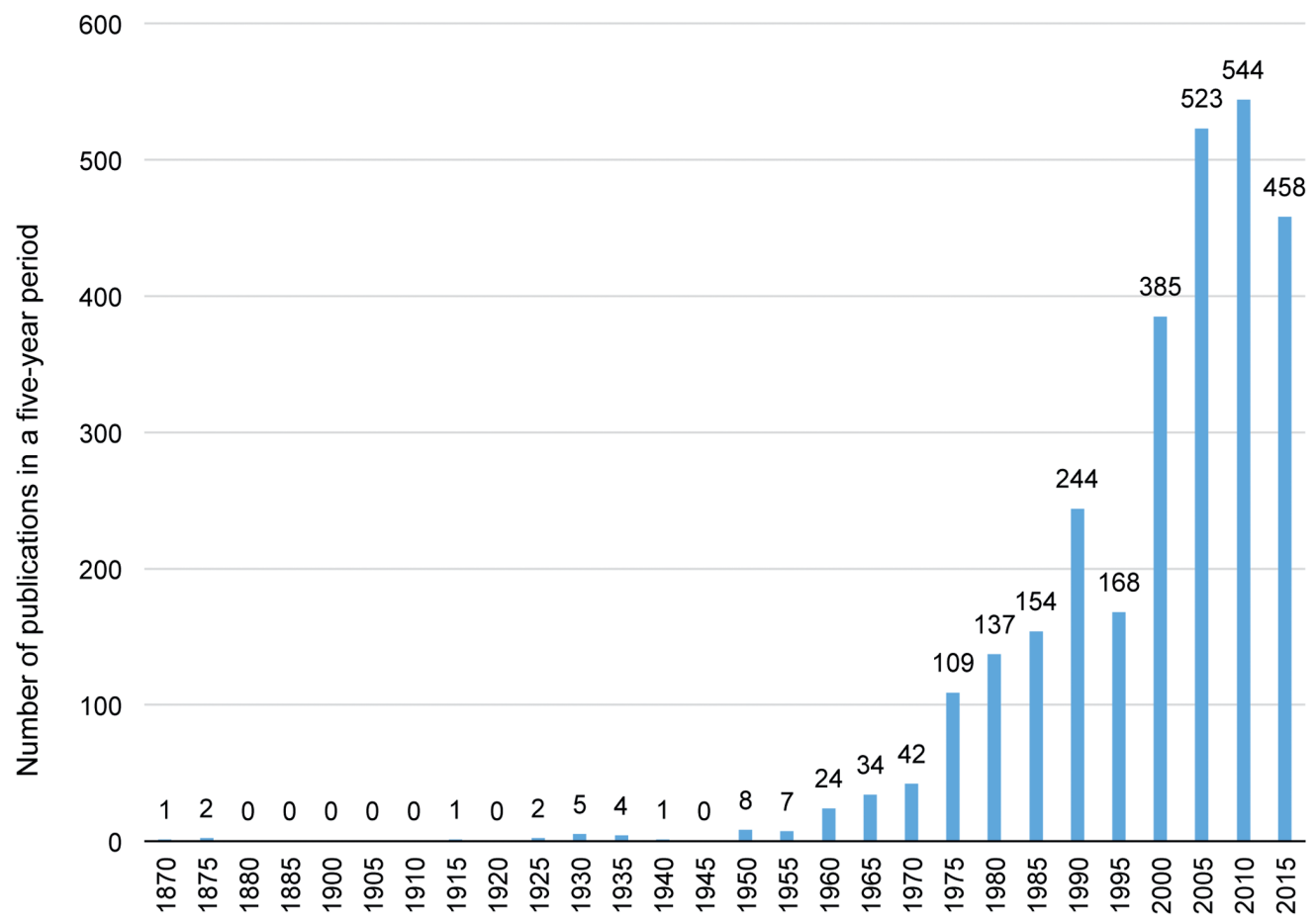

Five-year period

Fig. 2. Publishing dynamics of the works on crop weeds in Poland in the years 1870-2015 
Table 2. Thematic structure of research on crop weeds in Poland

\begin{tabular}{|c|c|}
\hline Thematic groups and subgroups & NoP \\
\hline 1. Variability, taxonomy and weed diagnostics & 92 \\
\hline 1.1. Taxonomy, diagnostics and variability of weeds & 73 \\
\hline 1.2. Chemical content of weeds & 19 \\
\hline 2. Biology and weed development & 172 \\
\hline 2.1. Soil diaspore bank & 72 \\
\hline 2.1.1. Seed circulation in agricultural ecosystems & 26 \\
\hline 2.1.2. Content of seeds in the soil and their storage & 44 \\
\hline 2.1.3. Bank of vegetative diaspores & 2 \\
\hline 2.2. Germination biology & 33 \\
\hline 2.3. Developmental biology & 52 \\
\hline 2.4. Phenology (seasonal changes in weeds and weediness) & 14 \\
\hline 3. Interactions between weeds and the environment & 579 \\
\hline 3.1. Allelopathy (weed impact on other plants) & 58 \\
\hline 3.2. Effect of ecological factors on weeds & 521 \\
\hline 3.2.1. Effect of natural factors - climatic and soil factors & 94 \\
\hline 3.2.2. Effect of anthropogenic factors & 427 \\
\hline 3.2.2.1. Weed response to phytohormones and herbicides & 133 \\
\hline 3.2.2.2. Weed response to agrotechnical treatments & 280 \\
\hline 3.2.2.3. Effect of seed material contamination on weediness & 14 \\
\hline 4. Segetal flora and vegetation: structure, distribution and dynamics & 931 \\
\hline 4.1. Flora and communities of segetal bryophytes & 4 \\
\hline 4.2. Segetal vegetation: characteristics and distribution & 309 \\
\hline 4.2.1. Phytosociological characteristics of segetal communities & 114 \\
\hline 4.2.2. Geographical distribution of segetal communities & 195 \\
\hline 4.3. Segetal flora and vegetation: structure and dynamics & 569 \\
\hline 4.3.1. New and potential weeds & 53 \\
\hline 4.3.2. Expansion and crop threat & 152 \\
\hline 4.3.3. Receding, vulnerable and endangered species & 233 \\
\hline 4.3.4. Changes in flora and vegetation in time (permanent plots, succession) & 131 \\
\hline 4.4. Ecological groups of segetal weeds & 12 \\
\hline 4.5. Phyto-indication & 37 \\
\hline 5. Weediness of different crop types, crop fields and fallow lands & 821 \\
\hline 5.1. Weeds of different crop types & 434 \\
\hline 5.1.1. Cereals & 181 \\
\hline 5.1.2. Root crops & 61 \\
\hline 5.1.3. Rapeseed & 11 \\
\hline 5.1.4. Maize & 14 \\
\hline 5.1.5. Flax & 15 \\
\hline 5.1.6. Legume crops & 14 \\
\hline 5.1.7. Vegetable crops & 28 \\
\hline 5.1.8. Stubble fields & 28 \\
\hline 5.1.9. Horticultural and orchard crops and flower beds & 18 \\
\hline 5.1.10. Glasshouse crops & 1 \\
\hline 5.1.11. Energy plants & 31 \\
\hline 5.1.12. Mustard, buckwheat, hemp and dye plant crops & 6 \\
\hline 5.1.13. Transgenic plants & 2 \\
\hline 5.1.14. Special crops & 11 \\
\hline 5.1.15. Grassland & 10 \\
\hline 5.1.16. Weediness monitoring & 3 \\
\hline 5.2. Weediness of crop fields (generally) & 196 \\
\hline 5.3. Weediness of crop fields in protected areas & 58 \\
\hline 5.4. Weediness of fallow lands, wastelands and stubble fields & 73 \\
\hline 5.5. Disturbance and catastrophe-related weediness & 10 \\
\hline 5.6. Medicinal and edible weeds & 50 \\
\hline 6. Extinction and protection & 24 \\
\hline 6.1. Refuges of segetal field weeds & 9 \\
\hline 6.2. Weed protection & 15 \\
\hline 7. Weeds of archaeological localities & 35 \\
\hline 8. Research methodology & 77 \\
\hline 9. Other aspects - general issues, discussions, ethnobotany and other issues & 122 \\
\hline
\end{tabular}

Explanation: $\mathrm{NoP}$ - number of publications 


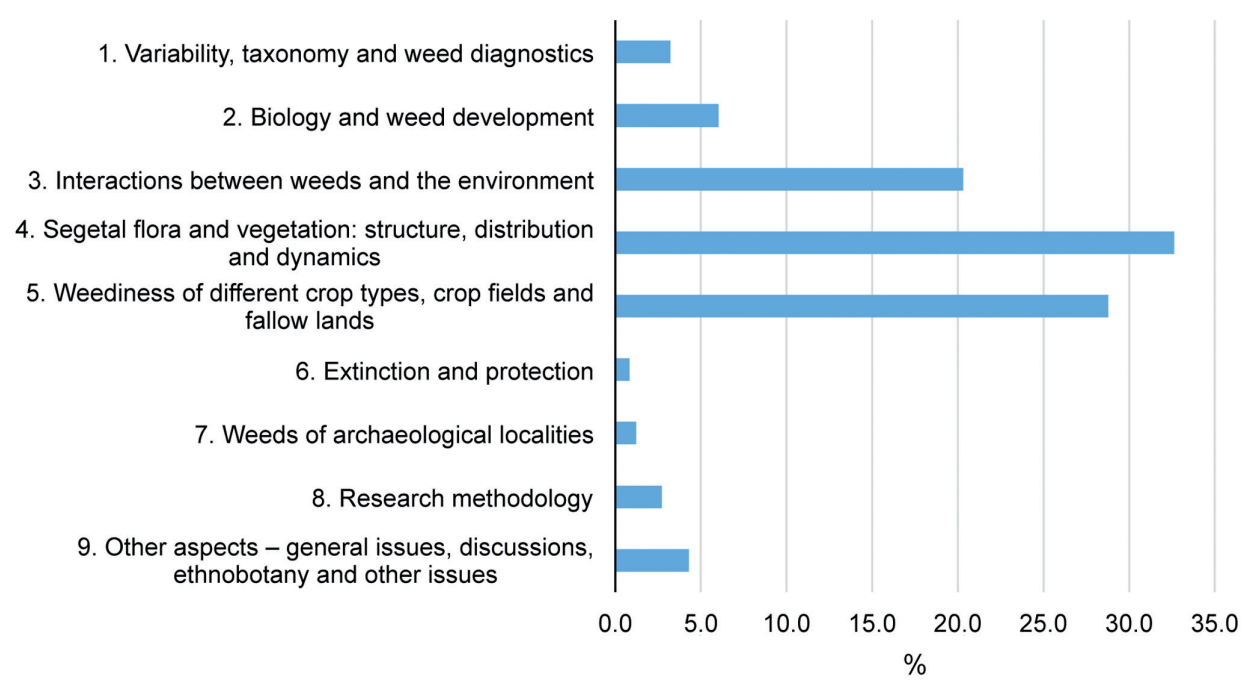

Fig. 3. The division of Polish publications on crop weeds into the main thematic groups

to three thematic groups (Fig. 3). Every third publication concerns the structure and dynamics of segetal flora and vegetation (group 4). The papers on weediness of arable fields and fallow lands (group 5) are almost as numerous. Every fifth publication addresses the problem of interactions between weeds and the environment (group 3).

There is also a significant share of publications on the biology and growth of weeds (group 2) and, to a lesser extent, variation, taxonomy and diagnostics of weeds (group 1) and methodological problems (group 8). In addition, two thematic areas deserve attention, namely, the problem of extinction and protection of weeds (group 6) and the occurrence of weeds in archaeologi- cal sites (group 7). The classification adopted here is supplemented by multi-topic publications on many of the above-mentioned problems (group 9).

\subsection{Characteristics of thematic groups}

The first thematic group is differentiated into two subgroups (Table 2). Subgroup 1.1. includes publications on morphological and anatomical variability of weeds, its taxonomic consequences and the use of structural features for the diagnosis of arable crops. Papers on this subject have been published regularly since the midtwentieth century and, in the 21 st century, their number shows a clear upward trend (Fig. 4). However there are fewer publications on the chemical composition

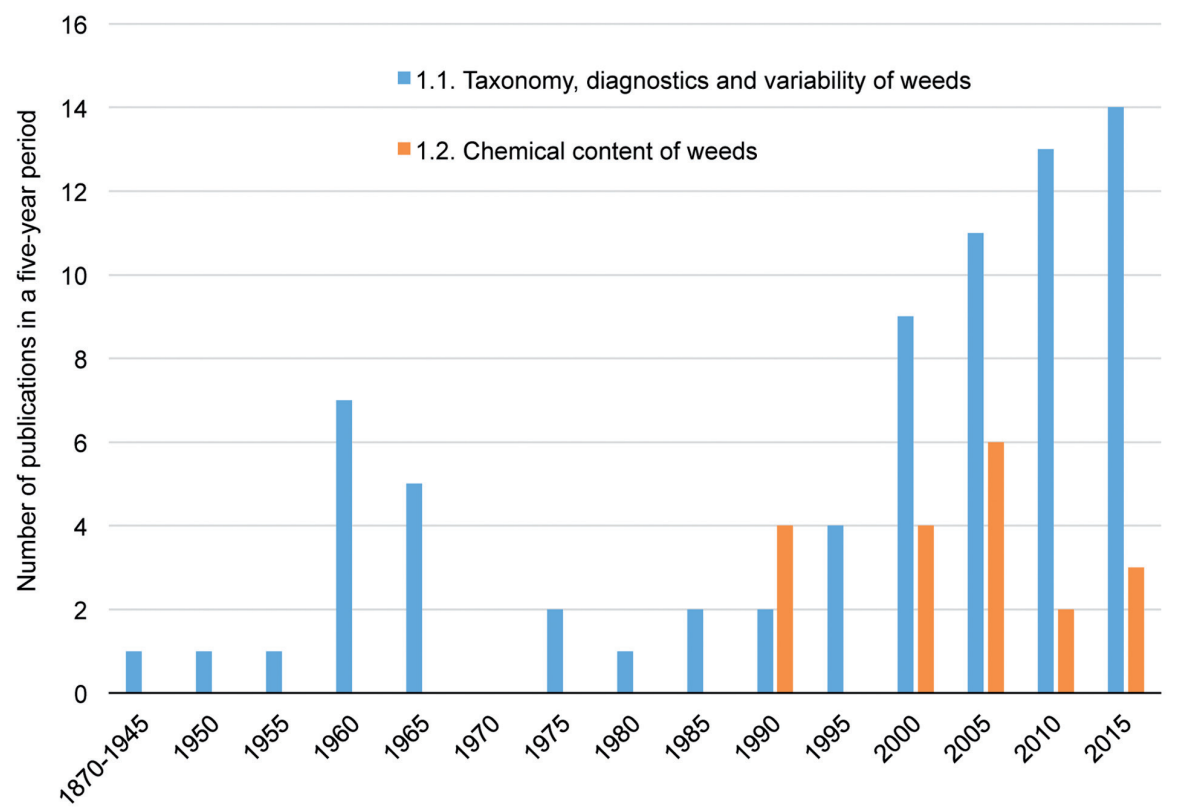

Fig. 4. Publishing dynamics of the works on variability, taxonomy and diagnostics of crop weeds in Poland in 1870-2015 


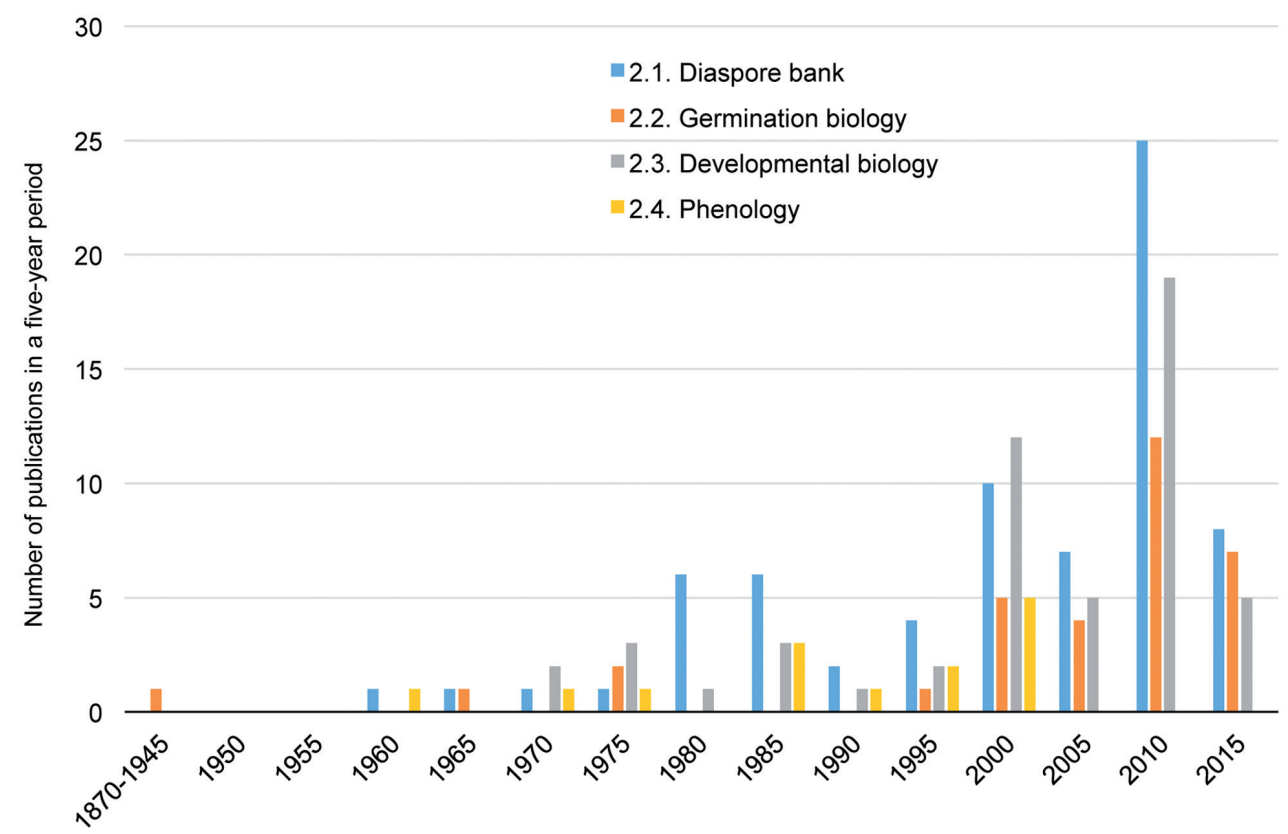

Fig. 5. Publishing dynamics of the works on biology and crop weed development in Poland in 1870-2015

of weeds and using these data in chemotaxonomy (subgroup 1.2). They have been published only since 1985 (Fig. 4).

The second thematic group includes 172 publications divided into four subgroups (Table 2). The largest among them is the subgroup of papers on the soil diaspore bank (2.1). The first work on this subject was published as early as in the years 1955-1960. The interest in the soil diaspore bank research was systematically growing to reach its peak in the years 2005-2010 (Fig. 5). Within the scope of this publication, three topics were considered: seed circulation in agricultural ecosystems (2.1.1), the species composition of the seeds in the soil and their storage (2.1.2), and the bank of vegetative propagules (2.1.3). Two further subgroups include research on germination (subgroup 2.2) and other aspects of weed growth and development (2.3). The second thematic group is complemented by papers in the field of phenology (2.4), which appeared quite irregularly in the years 1960-2000 (Fig. 5).

The third thematic group includes 579 publications and is differentiated into several levels (Table 2). This group is dominated by papers describing the influence of environmental factors on weeds (3.2), including the impact of natural (3.2.1) and anthropogenic (3.2.2) factors. Nearly half of the third group are publications

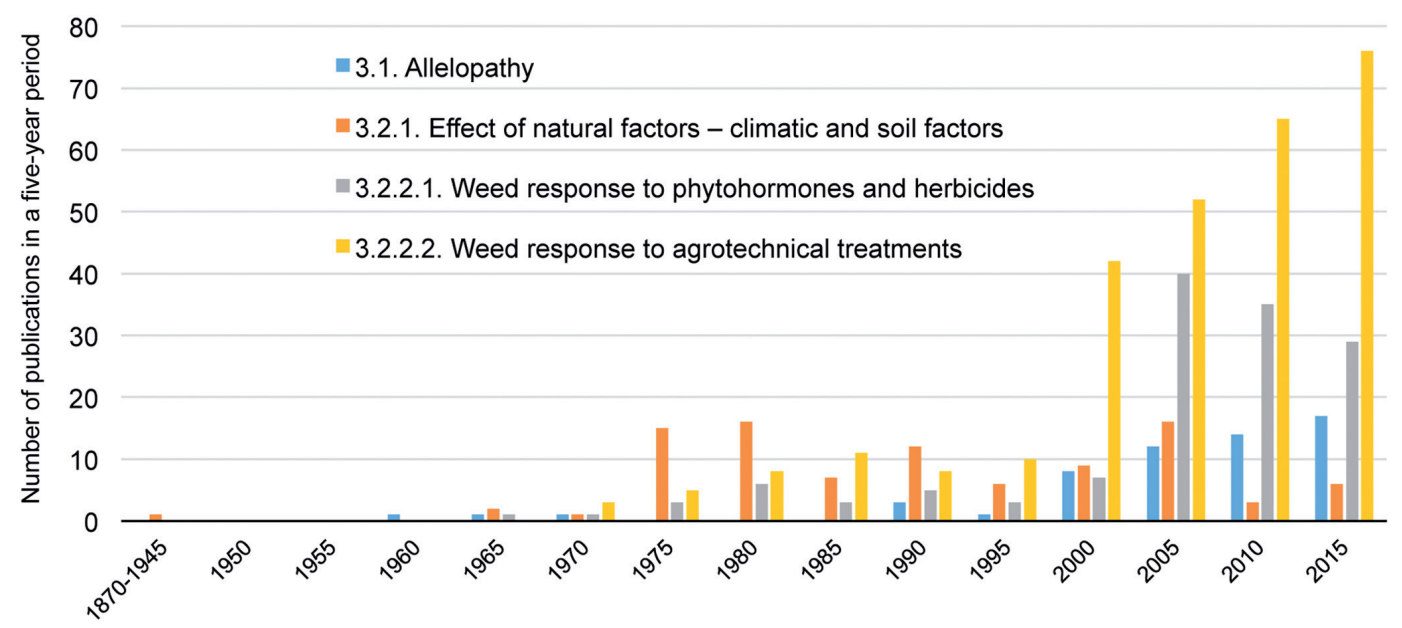

Fig. 6. Publishing dynamics of the works on interactions between weeds and the environment in Poland in 1870-2015 


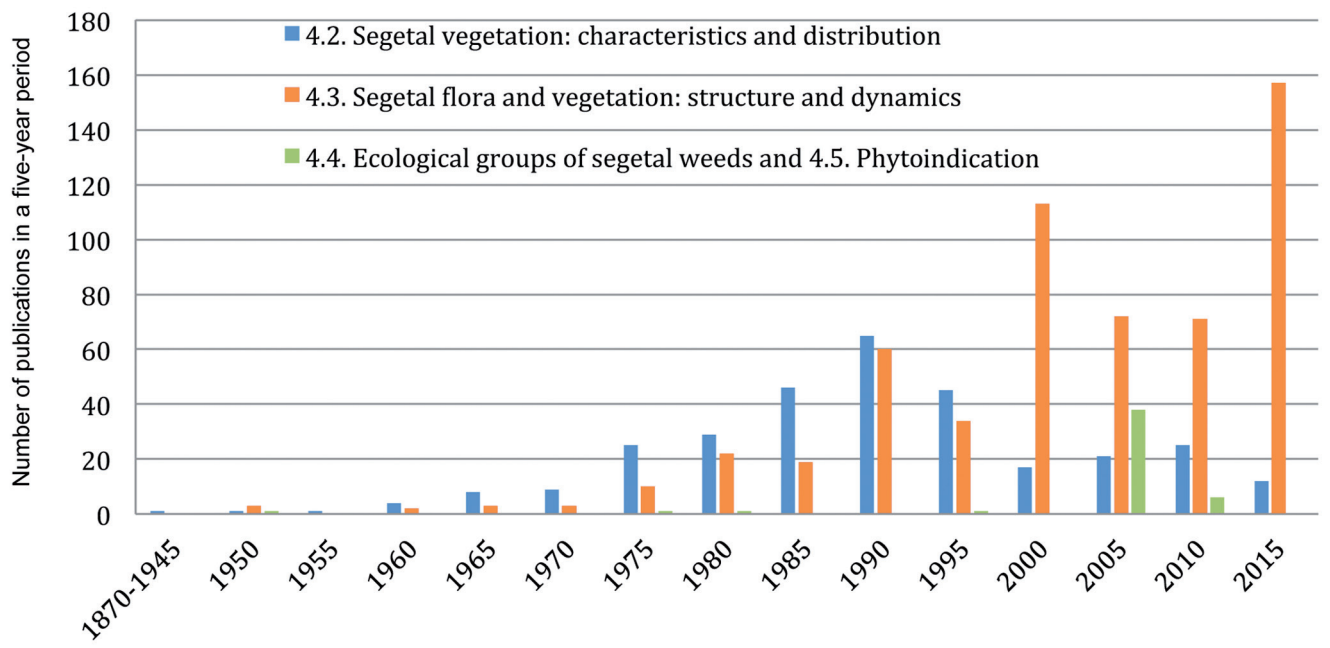

Fig. 7. Publishing dynamics of the works on structure, distribution and dynamics of segetal flora and vegetation in Poland in 1870-2015

describing weed response to agrotechnical treatments (3.2.2.2). The first of them appeared in the years 19651970, while in the last decade, over a dozen papers in this field have been recorded annually (Fig. 6). There is also a very large group of papers on the response of weeds to phytohormones and herbicides (3.2.2.1). Most publications on this subject appeared in the years 20002005. So far, less attention has been paid to the effect of seed material contamination on weediness (3.2.2.3). The influence of natural factors, in particular, climate and soil conditions (3.2.1), on weediness was analyzed in nearly 100 publications, the number of which is distributed quite evenly in the years 1960-2015. The third thematic group is complemented by papers on the weed impact on other plants (3.1). This interesting phenomenon aroused the interest of researchers already in the mid-twentieth century, but only in the last 15 years, the number of papers devoted to allelopathy has clearly taken on importance (Fig. 6).

The fourth thematic group is not only the most numerous (931 papers), but also characterised by multi-level differentiation (Table 2). On the first level of the division, there are five subgroups. The two largest subgroups concern segetal flora and vegetation and cover together over $90 \%$ of publications. One of them (4.2) focuses only on the phytocoenotic level, especially the phytosociological characteristics (4.2.1) and the distribution of cropland weed communities (4.2.2). The second subgroup (4.3) consists of more comprehensive publications devoted to both segetal flora and vegetation. The scope of problems is broad and covers such phenomena as: new and potential crop weeds in Poland (4.3.1), particularly, expansive and crop threatening weeds (4.3.2), receding, vulnerable and endangered species (4.3.3) and changes in flora and vegetation in time, including the results of research conducted on permanent plots and the phenomenon of succession (4.3.4). It is worth noting that the period of phytosociological paper domination in 1965-1995, was followed by a period in which floristic and phytocoenotic problems were treated with equal attention. This trend has been growing since 2000 (Fig. 7). The fourth thematic group also includes three smaller but notable subgroups: 4.1 - Flora and communities of segetal bryophytes, 4.4 - Ecological groups of segetal weeds, and 4.5 - Phyto-indication. The small representation of papers on these subjects reflects the conviction that bryophytes play a less important role not only in the weediness, but also in the characteristics of field habitats. In addition, these works draw attention to the advantage of the phytosociological methodology in the sense of the Braun-Blanquet school over a methodology based on ecological groups and bioindication (Fig. 7).

The fifth thematic group is not much smaller (821 papers) than the fourth group. In contrast to the latter group, it includes publications focused on weed infestation of crops, arable fields and special habitats, not on the characteristics of segetal flora or weed communities (Table 2). The division of this group shows a broad interest of researchers in the weeds of many plants cultivated in Poland (5.1), with the majority of papers focused on the weeds of cereals (5.1.1) and root crops (5.1.2). Definitely less numerous, but also deserving attention are publications on weeds occurring in the so-called energy crops (5.1.11) and papers on stubblefield weeds (5.1.8). The problem of weed infestation in arable fields was also analyzed in some specific aspects, e.g., in relation to fields occurring in protected areas (5.3), in the context of ecological disasters - first of all, catastrophic precipitation (5.5), or in relation to 


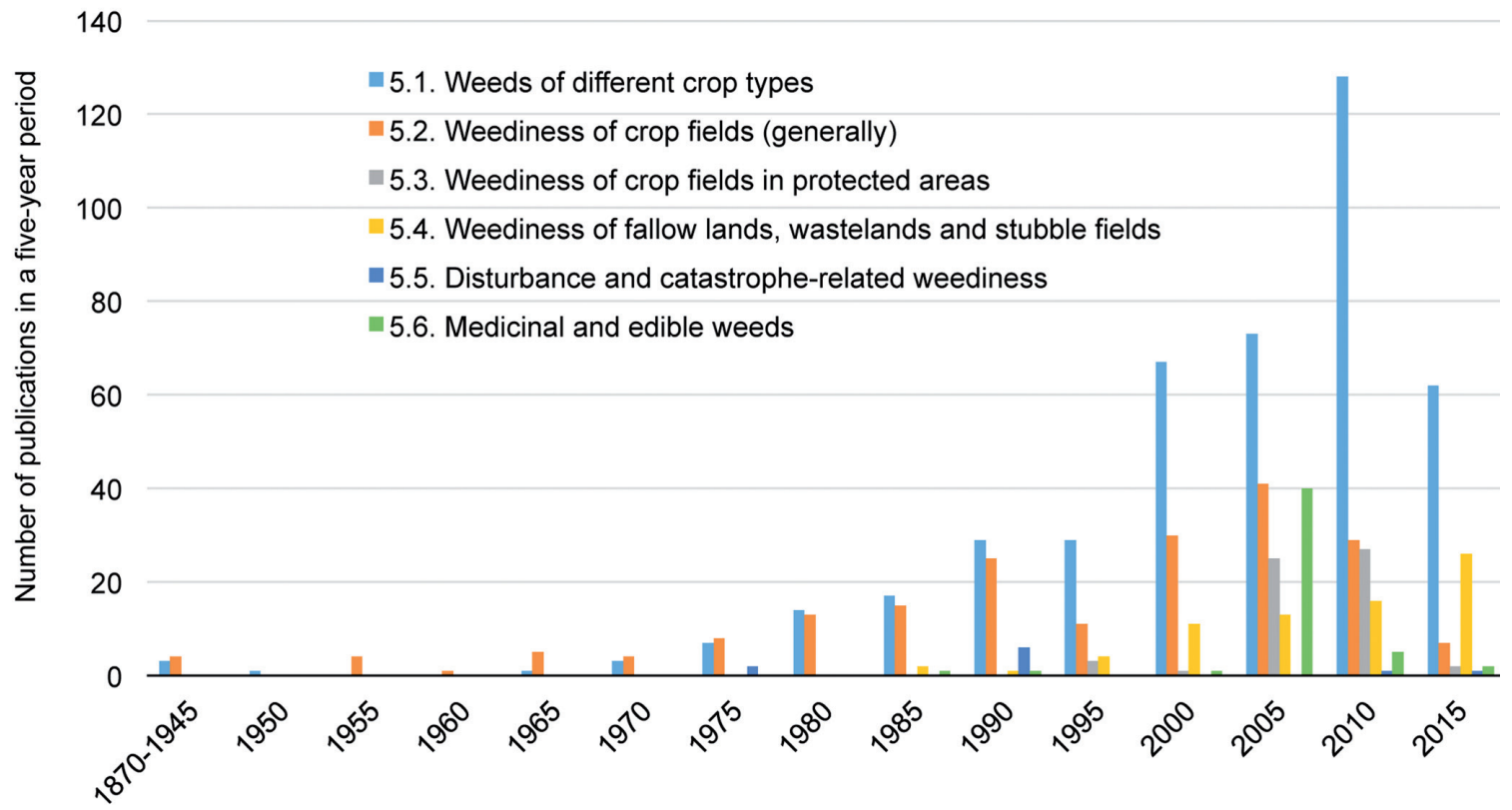

Fig. 8. Publishing dynamics of the works on weediness of different crop types, crop fields and fallow lands in Poland in 1870-2015

crop weeds of significant importance (5.6). The peak of interest in weeds related to certain types of crops was in the years 2005-2010 (Fig. 8). During the same period, there were also issued many publications on weeds spreading on fallow lands (5.4) and weeds of useful importance (5.6).

The sixth group is not very numerous because, unlike some of the previously discussed, it includes works from a relatively narrow thematic scope (Table 2). The authors of these works focus on two issues: firstly, they identify the sites of endangered segetal weeds (6.1) and, secondly, they indicate the need and methods to protect this group of species (6.2). This subject refers directly to subgroup 4.3.3, however, works included in the sixth group are distinguished by a much stronger conserva- tion accent, i.e., they do not so much assess the degree of danger of particular species as formulate guidelines for practical protection of them. The first paper on this subject appeared in 1948, the next one after 25 years.

In the seventh thematic group, 35 papers on weeds observed on archaeological sites were distinguished. They fall within the scope of research on the relationships between contemporary flora and flora accompanying former human settlements.

The eighth thematic group brings together 77 methodological publications. Papers of this type appeared irregularly, most often in the years 1975-1980 and 2000-2005 (Fig. 9).

The ninth group includes general, review, discussion and multi-subject publications.

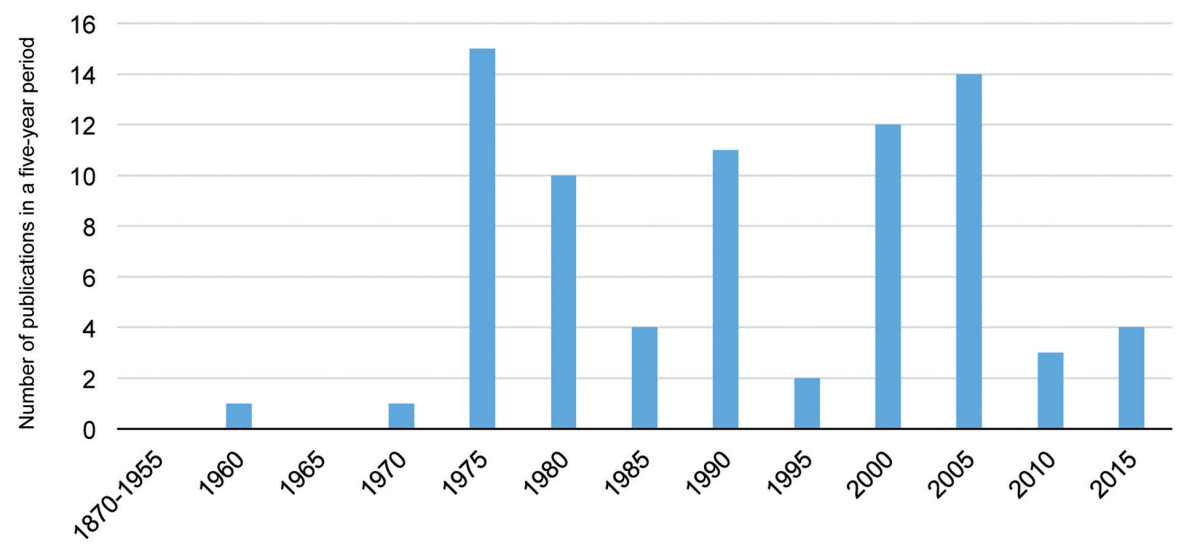

Fig. 9. Publishing dynamics of the works on the methodology of crop weed research in Poland in 1870-2015 


\section{Final remarks}

Although studies on crop weeds in Poland have a long tradition and have been conducted very intensively, their results are quite poorly disseminated in international literature. Using the Web of Science Core Collection database (2017), it was found that out of 16866 publications, whose main subject is described by the term "crop weeds", only in 175 cases, at least one of the authors is affiliated with Poland.

Similar proportions occur in relation to more specifically defined groups of issues, even those most often represented in the thematic structure of the Polish segetal bibliography. Example 1: among 1058 publications described as "crop weeds" and "vegetation", 21 are affiliated with Poland. Example 2: among 627 publications described by the terms "crop weeds" and "flora", 14 are affiliated with Poland. Example 3: among 1311 publications described by the terms "crop weeds" and "weed infestation", 46 are affiliated with Poland.

Taking into account the supra-local and even supraregional significance of many Polish studies on crop weeds, it seems necessary to present their results in the form of a review.

\section{References}

FALIŃSKi J. B. (ed.). 1968. Synantropizacja szaty roślinnej Polski. I. Neofityzm i apofityzm w szacie roślinnej Polski. Mater. Zakł. Fitos. Stosow. Uniw. Warsz., 25, 229 pp.

FALIŃSKi J. B. (ed.). 1971. Synantropizacja szaty roślinnej Polski. II. Flora i roślinność miast w związku z ich warunkami przyrodniczymi, dziejami i funkcja. Mater. Zakł. Fitos. Stosow. Uniw. Warsz., 27, 317 pp.

FALIŃSKI J. B. (ed.). 1972. Synantropizacja szaty roślinnej Polski. III. Teoretyczne i metodyczne podstawy badań nad synantropizacją szaty roślinnej. Phytocoenosis 1: 151-222.

FALIŃSKi J. B. (ed.). 1976. Synantropizacja szaty roślinnej Polski. IV. Wymieranie składników flory polskiej i jego przyczyny. Phytocoenosis 5(3-4): 159-409.

JACKOWIAK B. \& LATOWSKI K. 1996. Rozmieszczenie, ekologia i biologia chwastów segetalnych. Bibliografia polskich prac do roku 1995. [Distribution, Ecology and Biology of Segetal Weeds. Bibliography of Polish Works till 1995]. Prace Zakładu Taksonomii Roślin Uniwersytetu im. Adama Mickiewicza w Poznaniu [Publications of the Department of Plant Taxonomy of Adam Mickiewicz University in Poznań]. 4: 1-112. Polish/English text.

LATOWSKI K. \& JACKOWIAK B. 2001. Rozmieszczenie, ekologia i biologia chwastów segetalnych. Bibliografia polskich prac za lata 1996-2000. [Distribution, Ecology and Biology of Segetal Weeds. Bibliography of Polish Works in 1996-2000]. Prace Zakładu Taksonomii Roślin Uniwersytetu im. Adama Mickiewicza w Poznaniu [Publications of the Department of Plant Taxonomy of Adam Mickiewicz University in Poznań]. 11: 1-99. Polish/English text.

LATOWSKi K. \& JACKOWIAK B. 2006. Rozmieszczenie, ekologia i biologia chwastów segetalnych. Bibliografia polskich prac za lata 2001-2005. [Distribution, Ecology and Biology of Segetal Weeds. Bibliography of Polish Works 2001-2005]. Prace Zakładu Taksonomii Roślin
Uniwersytetu im. Adama Mickiewicza w Poznaniu [Publications of the Department of Plant Taxonomy of Adam Mickiewicz University in Poznań]. 16: 1-99. Polish/English text.

LATOWSKI K. \& JACKOWIAK B. 2011. Rozmieszczenie, ekologia i biologia chwastów segetalnych. Bibliografia polskich prac za lata 2006-2010. [Distribution, Ecology and Biology of Segetal Weeds. Bibliography of Polish Works 2006-2010]. Prace Zakładu Taksonomii Roślin Uniwersytetu im. Adama Mickiewicza w Poznaniu [Publications of the Department of Plant Taxonomy of Adam Mickiewicz University in Poznań]. 18: 1-130. Polish/English text.

LATOWSKI K. \& JACKOWIAK B. 2016. Rozmieszczenie, ekologia i biologia chwastów segetalnych. Bibliografia polskich prac za lata 2011-2015. [Distribution, Ecology and Biology of Segetal Weeds. Bibliography of Polish Works 2011-2015]. Prace Zakładu Taksonomii Roślin Uniwersytetu im. Adama Mickiewicza w Poznaniu [Publications of the Department of Plant Taxonomy of Adam Mickiewicz University in Poznań]. 20: 1-134. Polish/English text.

KORNAŚ J. 1950a. Niektóre interesujące rośliny synantropijne zebrane w okolicach Krakowa i Miechowa [List of Some Interesting Synanthropic Plants Collected in the Environs of Kraków and Miechów]. Acta Soc. Bot. Pol. 20(1): 119-125 (in Polish with English Summary).

KoRnAŚ J. 1950b. Zespoły roślinne Jury Krakowskiej. Część I. Zespoły pól uprawnych [Plant Communities of Jura Krakowska. Part 1. Plant Communities of Arable Fields]. Acta Soc. Bot. Pol. 20(2): 361:438 (in Polish with French Summary).

KoRNAŚ J. 1954. Z nowszych wyników badań fitosocjologicznych nad chwastami polnymi [The Newest Phytosociological Research Results on Field Weeds]. Post. Nauk. Roln. 5(29): 87-102 (in Polish). 
KORNAŚ J. 1959. Zespoły synantropijne (Synanthropic Associations]. In: W. Szafer (ed.). Szata Roślinna Polski, 1: 87-125. PWN Warszawa (in Polish).

MRSP 2017. Mały Rocznik Statystyczny Polski [Concise Statistical Yearbook of Poland]. Główny Urząd Statystyczny, Warszawa.

Rehman A. 1870. O formacjach roślinnych Galicyi. a. Obwód Żółkiewski. [Plant Formations of Galizia. a. District Żółkiewski]. Spraw. Kom. Fizjogr. 5 (in Polish).
Rehman A. 1871. O formacjach roślinnych Galicyi. b. Obwód Złoczowski. [Plant Formations of Galizia. a. District Złoczowski]. Spraw. Kom. Fizjogr. 5 (in Polish).

Tyniecki W. 1952. Kanianka (Cuscuta) [Dodder (Cuscuta)]. Rolnik 17: 241-248. 305-311 (in Polish).

Web of Science Core Collection database. 2017. Clarivate Analytics. 